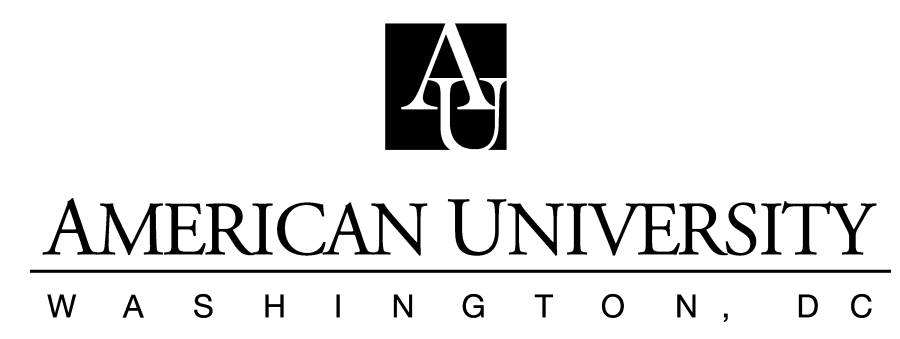

Department of Economics
Working Paper Series

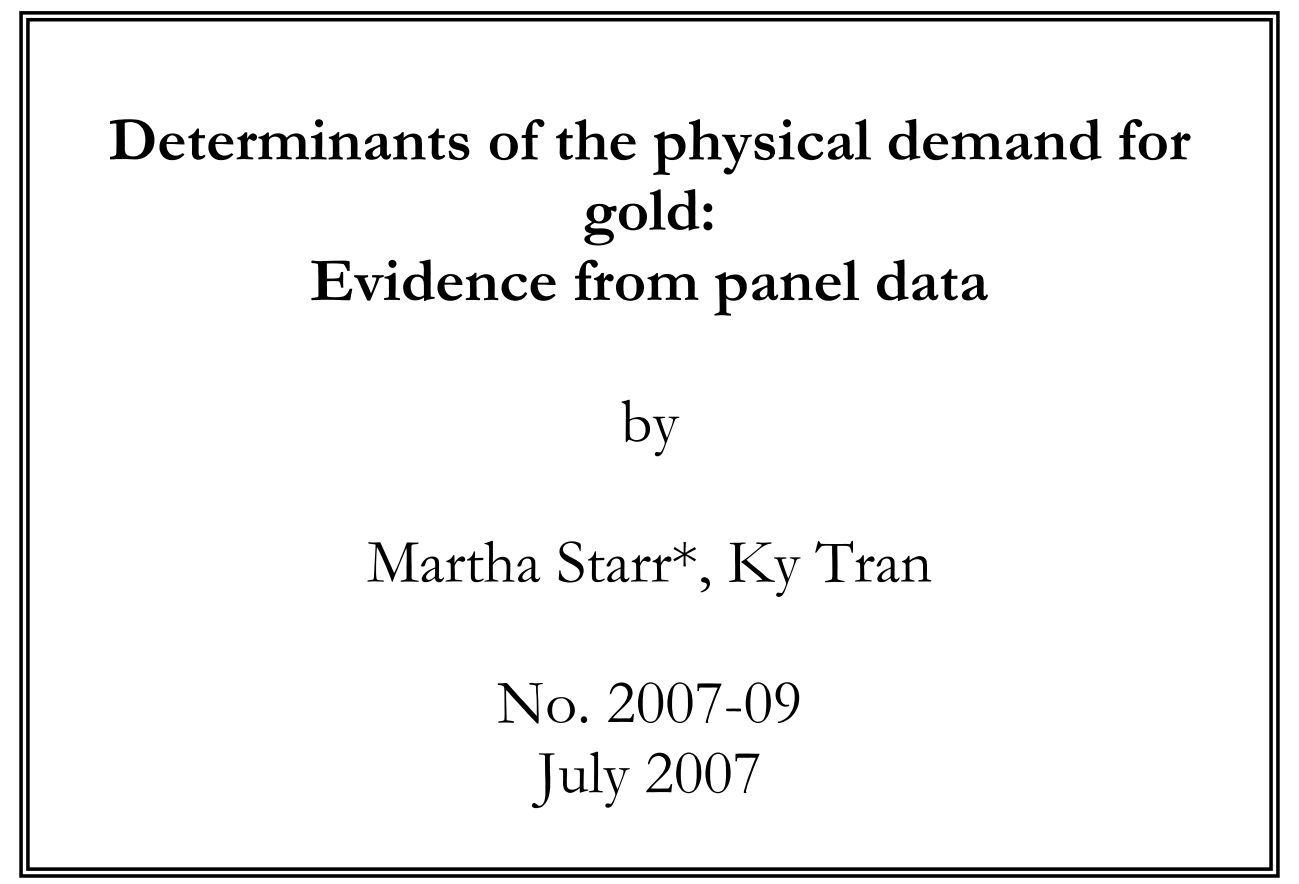

http://www.american.edu/academic.depts/cas/econ/workingpapers/workpap.htm

Copyright (C) 2007 by Martha Starr*, Ky Tran. All rights reserved. Readers may make verbatim copies of this document for non-commercial purposes by any means, provided that this copyright notice appears on all such copies. 


\section{Determinants of the physical demand for gold: Evidence from panel data}

\section{Abstract}

Although the role of gold in the world economy has declined since the gold standard was abandoned, it remains important as a central bank reserve, a hedge against risks, a barometer of geopolitical uncertainty, and an input for jewelry. While portfolio demand for gold has been well studied, determinants of physical demand are less understood. Certain emerging-market countries like China and India import substantial amounts of gold, with several factors that may contribute: low financial development, need for precautionary savings, and/or strong cultural valuation of gold itself. This paper uses panel data on gold imports of 21 countries to examine determinants of physical demand. We find that determinants of physical demand differ from those of portfolio demand, and that they differ between the developed and developing worlds.

Please address correspondence to:

Prof. Martha A. Starr, Dept. of Economics, American University, 4400 Mass. Ave. NW, Washington, DC 20016, USA. Email:mstarr@american.edu.

Key words: Physical gold demand, investment, savings, precautionary wealth JEL: O160, E210, G150 


\section{"Determinants of the physical demand for gold: Evidence from panel data"}

\section{Introduction}

Although the central role of gold in the world economy has declined since the demise of the gold standard in the 1970s, it is still a significant item in central bank reserves, it continues to be a sought-after store of value, and its price remains closely watched as an indicator of changing risk perceptions. While markets in which claims to gold trade have been well-studied (Beckers 1984; Bailey 1987; Sjaastad and Scacciavillani 1996; Capie, Mills and Wood 2005), considerably less attention has been paid to what is known as the 'physical demand' for gold -that is, acquisitions of gold in physical forms such as jewelry, bars, coins, and medallions. A considerable part of this market reflects demand from emerging-market countries where gold has traditionally been an important store of value and symbol of wealth. As shown in Figure 1, India and Pakistan alone account for about $1 / 5$ of world demand, with another $15-20 \%$ each coming from the Middle East and Turkey, and Greater China and other emerging-market countries of South East Asia; the share of demand from the G5 countries and Italy is on par with that of India and Pakistan. ${ }^{1}$ Expressed in per-capita terms, levels of gold imports are especially high in South and East Asia and the Middle East. As shown in Figure 2, for example, Vietnam's gold imports per capita were not far from those of France and Germany, despite the fact that per capita GDP in Vietnam is about $20 \%$ that of France or Germany.

Physical gold has a number of appeals as a store of wealth, especially in emerging-market contexts. First, because gold is highly portable and holds its value well in times of uncertainty, it is thought to provide a good hedge against economic, social, political, and personal risks.

Second, in countries where financial systems are in relatively early stages of development, the range of investment opportunities may be only starting to expand, and confidence in financial markets and institutions may be less than full. Thus, assets like gold that can be held outside of the financial system and hold their value in times of uncertainty remain of significant interest. A third and related point concerns the relatively low development of credit-markets in developing countries: because the scope for borrowing has been relatively limited, a higher priority is placed on building up precautionary wealth that could be liquidated to cover

\footnotetext{
${ }^{1}$ The term 'demand' as used in discussion of physical gold is roughly equivalent to the level of imports into a country in a given year. In any given year, world production of gold is quite small relative to the 'above ground' stock, but because that entire stock constitutes total potential supply, it is flows of gold between countries that are thought of as demand. Note that central banks are estimated to hold about one-fifth of the world's above-ground stocks of gold, although this share has been falling as the role of gold in central bank reserves has been steadily declining (see World Gold Council 2006).
} 
consumption needs in the event of an adverse shock. Jewelry is handy in this respect, because it can be worn and enjoyed in ordinary times with the understanding that it could be sold to cover consumption should a family's fortunes turn. A final point concerns the role of culture in sustaining the value associated with gold. In places like India, the Middle East, and China, where gold has traditionally been highly prized, the knowledge that others will regard gold as having timeless intrinsic value serves to reinforce perceptions of its social and monetary worth. That gold jewelry in developing countries is held as much for investment purposes as it is for personal adornment is reflected in the way in which it is sold. In developing countries, gold jewelry is typically high in carats and priced with minimal artistic mark-up over the value of the gold with which it is made -- whereas in developed countries, only a small share of jewelry is high in carats, and mark-ups over gold costs are much higher, consistent with much lower interest in its store-of-wealth aspect. ${ }^{2}$

Many previous studies have attempted to characterize determinants of demand for gold by examining high-frequency data on gold prices -- although these are primarily affected by portfolio-related purchases and sales of gold claims, rather than physical-gold transactions. In this regard, Capie et al. (2004) examined whether the hedging roles of gold had changed after the breakdown of the Bretton Woods, distinguishing between its role as an internal hedge against the domestic purchasing power of the dollar and that as an external hedge against changes in its external purchasing power. They found that gold was a good external hedge against exchange-rate fluctuations, although its value in this respect varied over time. Cai, Cheung, and Wong (2001) studied the behavior of the gold futures market. They found that gold futures prices were significantly affected by news about sales of gold reserves by central banks, political tensions in South Africa, and key U.S. macroeconomic indicators like inflation, unemployment, interest rates, and oil prices. However, reactions of gold prices to news about economic fundamentals were relatively small, compared to their effects on markets for Treasury bonds and foreign exchange.

There has been much less work on gold markets or gold demand in emerging-market countries. In an early study of gold demand in India in 1901-1913, Rao and Nagabhushanam (1960) found demand to rise strongly with income and to decline with price. Using cross-country data, Balassa (1990) found investment in gold to be higher in places where real interest rates were negative. Kutan and Aksoi (2004) study the market for gold in Istanbul. In their results, gold prices did not react much to CPI releases, suggesting it is not a good hedge against inflation; however, prices did react significantly to real-side news. Algahtani (1992) argued that, reflecting widespread interest in gold among investors in Kuwait, the world price of gold enters

\footnotetext{
${ }^{2}$ See World Gold Council (2007).
} 
significantly in the country's money-demand function, so that its fluctuations need to be considered by its monetary authorities in their policy decisions. Similarly Tran and Starr (2007) analyze the role of gold in monetary- and exchange-rate policy in Vietnam where, in the turbulent period after economic reform began, gold served not only as a store of value but also as a unit of account and medium of exchange for some types of transactions.

In a study with some similarity to ours, Haugom (1991) analyzed World Gold Council data on physical gold imports of developed and developing countries respectively. He found the gold demand of developed countries to be positively related to past demand and negatively related to the gold price, although the gold price seemed less important than economic and political factors in physical demand. The gold demand of developing countries was found to have somewhat different determinants: It was positively affected by U.S. economic growth (taken as a proxy for the strength of the world economy), and was significantly influenced by various measures of international economic and financial conditions.

A shortcoming of Haugom's study is that, because the data were for country groups rather than individual countries, it was not possible to investigate how national economic and financial conditions influenced demand for gold, nor was it possible to explore the role of socio-cultural factors in cross-country variations. To our knowledge no previous economic research has tackled the latter question, even though culture is regularly cited as the source of strong demand in certain parts of the developing world. As a notable example, Keynes (1913: 99) argued that India "wastes far too high a proportion of her resources in the needless accumulation of the precious metals", claiming that "The history of India at all times has provided an example of a country impoverished by a preference for liquidity amounting to so strong a passion that even an enormous and chronic influx of the precious metals has been insufficient to bring down the rate of interest to a level which was compatible with the growth of real wealth" (1936: 337). Refuting this view, Chandavarkar (1961) argued that Indians' gold holdings in fact reflected practical considerations rather than unreasonable preferences, and that when one looked carefully at data on gold holdings "the actual extent of misdirection of resources involved is much less than is commonly supposed." Determining whether crosscountry variations in gold demand in part reflect cultural factors is of course not possible without quantitative empirical work that establishes its determinants.

This paper presents estimates of factors affecting physical demand for gold, using panel data from the World Gold Council (WGC), which cover 21 countries for the period from 1992 to 2003. We examine the relative importance of a number of factors that may influence demand, 
including income growth, exchange-rate and inflation volatility, the gold price, the extent of the country's financial development, real returns to safe financial assets, and access to credit. The availability of panel data also enables us to measure persistent heterogeneities in physical gold demand across countries, as would be consistent with a role of socio-cultural factors. In brief, our results show that determinants of physical demand differ from those of portfolio demand, and that they differ between the developed and developing worlds.

\section{Data and methodology}

The present study analyzes annual data on physical gold demand compiled by the World Gold Council (WGC) and published in its quarterly reports on "Gold Demand Trends." 3 The WGC divides gold demand into four categories: jewelry, retail investment, industrial, and dental. Table 1 provides exact definitions of these categories and shows their relative importance in 1997-2002. The largest component of physical demand by far is jewelry, which accounted for $4 / 5$ of gold demand in these years. The second most important category is retail investment, which refers to gold coins and bars and accounted for $8.4 \%$ of gold demand. Together these two categories are referred to as 'consumer demand', and it is these categories that are analyzed in the present study. The other two categories - industrial and dental - together made up 10\% of physical demand, and are presumably driven by different factors than those influencing its consumer aspects. ${ }^{4}$

The data cover the annual gold imports of 21 countries over the 1992-2003 period. ${ }^{5}$ They pertain to identifiable end-use consumption as so exclude gold purchases of central banks. Six of the countries are high-income (France, Germany, Italy, Japan, the U.S., and U.K), while the remainder are emerging-market countries that are notable importers of gold. Appendix table 1 lists the countries in the sample, along with summary statistics on their per-capita gold imports. The sample composition entails a selection problem, insofar as countries that are significant importers of gold are far more likely to be included in the data than similar countries that are not. Still, the data are well-suited to characterizing the world market for physical gold, in that these 21 countries together account for $75 \%$ of world demand. ${ }^{6}$

\footnotetext{
${ }^{3}$ The World Gold Council bases its statistics on data compiled by the research group of GFMS, a precious-metals consultancy.

${ }^{4}$ Note that purchases by high net-worth individuals are considered to be institutional investment and are not included in the statistics.

${ }^{5}$ The WGC also collects data for Taiwan, the United Arab Emirates and Turkey, although these countries are not included in the present study. For the first two countries, data on the righthand side variables are generally not available; Turkey was not included due to problems with extreme variations in exchange rates and inflation over the sample period.

${ }^{6}$ If the data for Taiwan, the UAE, and Turkey were included, this figure would be $83 \%$.
} 
The econometric specification used to analyze gold demand is as follows:

$$
G_{i t}=\alpha G_{i t-1}+X_{i t-1}^{\prime} \beta+D_{t}^{\prime} \delta+z_{i}+\varepsilon_{i t}
$$

where Git is per-capita imports of gold by country $i$ in period $t$, measured in grams and expressed in log terms. Current-period demand is modeled as a function of lagged demand, which seems appropriate given that gold's perceived value may depend in part on how highly others seem to value it, so that recent strong demand presently would bolster demand in future periods also. $X_{i t-1}$ is a vector of characteristics expected to cause variations in physical gold demand across countries and over time, with specifics to be given below; all variables are included in lagged form to reduce problems of possible endogeneity. $D_{t}$ is a vector of year dummies intended to capture effects of changes in world-market conditions or geopolitical factors that are common across countries. The $z_{i}$ are included to reflect persistent unobserved heterogeneities across countries in gold demand, which one would expect to be important if socio-cultural factors play a notable role. Finally the term $\varepsilon_{i t}$ represents random variation.

Table 2 presents the list of variables included in $\mathrm{X}_{\mathrm{it}-1}$, along with exact definitions and data sources. A first important variable is GDP per capita, here measured in constant US dollars using purchasing-power-parity exchange rates. ${ }^{7}$ One might expect gold to be a luxury good, with a country's imports rising strongly as its per-capita income increases. Although the empirical relationship shown Figure 2 is not suggestive of such a relationship, the observed pattern may reflect confounding effects of other variables associated with income level; for example, gold imports may be high in lower-income countries due to lack of investment alternatives, so that once other such effects are controlled for, the expected positive effect of income per se may become apparent. We also include growth in per capita GDP in the regression, to investigate whether recent income changes affect gold demand, given the country's income level. As another dimension of income effects, the regressions also include the standard deviation of growth in GDP per capita, measured on a 5-year moving average basis -- to determine whether recent income volatility affects gold acquisitions.

The next several variables correspond to those found to be important in studies of gold prices, although here the measures relate to national economic and financial conditions rather than conditions in the U.S. or on world markets. Thus, the regressions include: exchange-rate volatility, measured as the standard deviation of changes in the national currency's nominal exchange rate vis-à-vis the U.S. dollar in the past five years; the level of inflation as measured

\footnotetext{
${ }^{7}$ Measuring GDP per capita in purchasing power parity exchange rates is intended to capture effects of variations in incomes across countries on gold demand, getting rid of confounding effects of differential inflation rates and exchange rate changes.
} 
from the consumer price index; inflation volatility, measured as the standard deviation of inflation in the previous five years; and the change in the real price of gold, measured by converting the most widely quoted world price of gold (the 'London p.m. fix') into constant domestic-currency terms. ${ }^{8}$ Previous studies suggest that increased volatility in exchange or inflation rates, or a higher inflation rate, would tend to increase gold demand -- although as mentioned, it is not clear that these factors affecting trade in gold claims are similarly important for physical demand. Whether increases in the real price of gold would increase or decrease gold demand is not obvious a priori: on one hand, as with any normal good, one would expect an increase in its price to reduce the quantity demanded, ceteris paribus; but on the other, recent price increases may increase interest in acquiring gold for the investment returns, if recent price increases are interpreted as signaling a likelihood of further increases in the future.

A final set of variables is intended to gauge how investment alternatives and access to borrowing affect physical gold demand. Here we include (a) the value of private-sector credit outstanding relative to GDP, where we expect to find that gold demand declines as access to borrowing improves, ceteris paribus, reflecting a dwindling need for precautionary saving; (b) the real interest rate on bank deposits, where we expect that demand for gold may fall as returns to safe financial assets increase; and (c) the value of total stock-market capitalization relative to GDP, where we again expect that interest in gold may decline as the size of financial markets relative to economic activity increases.

A number of econometric problems arise in estimating (1). Of course, because the data have a panel structure, OLS estimates of (1) will be biased due to failure to control for unobserved heterogeneity. Estimating a fixed-effects model will take care of this problem, although the presence of a lagged dependent variable on the right-hand side is also a cause of bias. Arellano and Bond (1992), Arellano and Bover (1995) and Blundell and Bond (1998) developed ways of overcoming this problem using generalized methods of moments (GMM). In the original Arellano-Bond method, first-differences of pre-determined and endogenous variables are instrumented using lags of their own levels. However, lagged levels can be poor instruments for first differences if series are highly persistent and/or the variance associated with fixed-effects is large compared to that associated with random shocks. Thus, Arellano-Bover and BondBlundell develop systems-GMM estimators that add an equation in levels to be estimated with the equation in first difference. While widely used, it is not clear that these approaches are appropriate for the present application, given that their properties are derived for large- $\mathrm{N}$, small-T applications, which is not case the case here. An alternative is to run the fixed-effects

\footnotetext{
${ }^{8}$ Smith (2002) discusses the London gold market.
} 
panel-data model with a correction for the bias associated with the lagged dependent variable, as suggested by Bruno (2005). With none of these approaches obviously dominating the others in the present case, our approach is to estimate all five models and give weight to those findings that are robust to changes in specification.

A final set of issues concerns appropriate levels of disaggregation in analyzing the data. A priori it would seem desirable to estimate (1) for developed and developing countries separately, given the possibility that determinants of gold demand may differ between them. However, with only six developed countries in the sample, a model estimated from a developed-country sub-sample in particular may well not be meaningful. Thus, our approach is to estimate (1) first for all 21 countries together, then for the sub-sample of developing countries, and last for the sub-sample of developed countries, bearing in mind that results for the sub-samples have to be interpreted with caution. Similarly, it would seem desirable to estimate models of jewelry demand and retail-investment demand separately, given that factors driving one may not be the same as factors driving the other. However, levels of retail-investment demand tend to be quite small and fluctuate a lot from year to year, most likely making it difficult to pin down its determinants. Thus, we estimate (1) first for total consumer demand, then for jewelry and retail-investment demands respectively, again bearing in mind that the more disaggregated results are likely to lack precision.

\section{Results}

Table 3 shows results based on estimating (1) for total consumer demand (jewelry plus retail investment) and data from all 21 countries. All five specifications show a considerable amount of persistence in physical demand for gold, with estimates of the autoregressive coefficient ranging from .51 in the Arellano-Bond specification to .87 in pooled OLS. While we cannot be sure where the true coefficient falls in this range, the estimates all suggest that, following a positive shock to gold demand, it will take a while for demand to revert back to its previous level, as would be expected if part of people's rationale for acquiring gold reflected in part the level of interest their fellow nationals seemed to have in it.

As mentioned above, Figure 2 would not lead us to suspect an appreciable relationship between GDP per capita and physical demand for gold, although other factors need to be controlled for to determine whether this impression is right. The results in Table 3 suggest that indeed percapita income is not a significant determinant of gold demand, ceteris paribus. At the same time, however, in four of the five specifications gold demand is found either to be negatively related to recent income growth, and/or to be higher in periods of income volatility. These 
findings are consistent with idea that physical gold is especially valued in times and places when economic conditions have been weak or unsettled.

In contrast, the factors found in other studies to drive portfolio demand for gold -- exchange rate volatility, inflation, inflation volatility, and the gold price -- turn out not to be systematic determinants of physical demand for gold: in only two cases are there significant effects at a $10 \%$ level or better (the level of inflation in the fixed-effects model and the gold price in the GMM-difference model). Because there are minimal lags and transactions costs associated with buying and selling claims to gold, it is possible to profit by adjusting one's holdings in response to high-frequency news about expected risks and returns -- whereas it is not worthwhile to make such adjustments when buying and selling physical gold due to time lags and transportation costs associated with acquiring or relinquishing material holdings.

In all specifications, the size of the private credit market relative to GDP is estimated to have a negative effect on gold demand, although the results are statistically significant in two cases only. At the same time, contrary to expectations, in four of five specifications stock-market capitalization is estimated to have a positive and significant effect on physical gold demand. This result seems to reflect a 'wealth effect' wherein strong growth in stock prices boosts physical demand for gold, in both the jewelry and retail-investment categories (see below). Thus, while the relationship between per-capita income and gold imports may not show gold to be a luxury good, the association of bullish stock markets with gold jewelry imports does.

The results also suggest that there are indeed persistent unobserved heterogeneities in gold demand, consistent with a role of socio-cultural factors. The estimated coefficients differ notably between the pooled OLS and fixed-effects models, as would be expected if the former was biased due to uncontrolled, unobserved heterogeneity. According to results of the fixedeffects model, in fact persistent unobserved differences across countries account for $68 \%$ of the variation in gold demand not associated with included explanatory variables. Of course, socio-cultural factors may be only one such difference, but they seem likely to make an important contribution. Thus, for example, estimates of the country-specific fixed-effects indeed show demand to be relatively high in those countries where gold is thought to be highly valued culturally: China, India, Pakistan, the Middle East (Egypt, Kuwait, Saudi Arabia) and certain countries of Southeast Asia (Indonesia, Thailand, and Vietnam); see Table 4.

Table 5 shows the results from estimating (1) separately for the developing- and developedcountry sub-samples. There are several interesting points to note. First, in most specifications, the estimated effects of lagged demand are considerably lower in the developed-country subsample than they are in the developing-country sub-sample. In other words, positive shocks to 
demand dissipate more quickly in developed countries than in developing ones, as would be the case if knowledge of recent strong demand had more modest effects in raising demand presently. Second, whereas results using the developing-country sub-sample show no significant effect of per-capita income on gold demand, among the developed countries the effect is positive, significant and large in three of the five specifications. Conceivably this may reflect a view of physical gold in advanced-industrial settings, as discretionary spending for personal adornment, that is not shared in the developing world. Third, the idea of gold being something purchased in uncertain times shows up in both subsamples: in both cases, estimated coefficients show higher recent income growth to be negatively related to gold demand, and/or that recent income volatility tends to raise it. Fourth, in three of five specifications using the developed-country sub-sample, recent inflation volatility is associated with higher gold demand, consistent with findings from studies of gold prices. Finally, the result that gold demand is significantly higher where private credit markets are less developed shows up in three of five specifications for developing countries, but only one for the developed-country group. Possibly this reflects the greater role of motives to acquire holdings of gold as precautionary wealth in developing versus developed countries.

Finally, Table 6 presents results of the models for jewelry and investment demand estimated separately. Not surprisingly, most of the significant results mentioned for overall consumer demand are also found for jewelry demand - which is to be expected given that jewelry represents $90 \%$ of total consumer demand. Interestingly, from estimating the models separately we can see that the strong autoregressive element of overall demand is driven by jewelry demand; investment demand is only modestly influenced by its past level. In general, though, there are very few results significant for investment demand - consistent with the idea that these flows are quite small and noisy. Still, one effect that is significant in three of five specifications for investment demand is stock-market capitalization. This again suggests a 'wealth effect', wherein higher stock-market wealth boosts purchases not only of jewelry but also of collectible gold items like coins and medallions.

\section{Conclusions}

To summarize, our econometric analysis has three main results. First, determinants of physical demand for gold are indeed different from determinants of demand for gold claims, in a way that is to be expected: whereas claims are bought and sold with keen interest in expected price changes, financial-hedging variables play little role in physical demand for gold; rather, physical demand reflects an interest in actually acquiring the gold. Second, there is persistent unobserved heterogeneity across countries in the amount of gold they demand. While a variety of factors could contribute to this (such as unmeasured attributes of domestic financial 
institutions and markets), culture seems quite likely to be involved, given that the countries that persistently demand more gold than would be expected from their characteristics are also those known for having traditions in which gold plays a part, as in India and China where gifts of gold jewelry are customarily given for weddings or holidays. ${ }^{9}$ Finally, there are some notable differences between developed and developing countries in determinants of gold demand. In developed countries, hedging-type variables have some effect on gold demand, and gold demand rises with per-capita income, as would be expected if gold is valued as discretionary personal adornment. In contrast, in developing countries demand is higher when income has fallen or been volatile recently, does not systematically rise with per capita income, and is negatively related to the development of private credit markets. Thus, in emerging-market settings the role of gold as precautionary savings is at least as important as, if not more important than, its personal-adornment aspect.

Our results make clear why policy measures intended to discourage investment in physical gold tend to be ineffective. As a notable example, from 1962 till the 1990s the government of India imposed a number of restrictions on imports intended to discourage "non-productive" investment in gold in favor of investment in productive capital (Bhattacharya 2002). People were also encouraged to exchange physical gold holdings for government gold bonds, although only a small portion of the gold stock was ever exchanged. Our results confirm what was said at the time: that in a setting like India, where physical gold has strong aesthetic appeal and deeply-rooted socio-cultural associations, financial assets of comparable monetary value are very imperfect substitutes for it. Since the 1990s, the Indian government has deregulated the gold market significantly (see Bhattacharya 2002).

Nonetheless, our research also suggests that, despite the extraordinary growth rates registered in India and China in recent years, higher incomes will not necessarily translate into booming demand for gold. While rising wealth appears to raise physical gold demand in both advancedindustrial and emerging-market economies, effects of rising income are apparent in the former only; in the latter, income-related effects have more to do with adverse than positive trends. Of course, given the cultural and historical roles of gold in these places, one should expect their demand to be persistently strong in years ahead - but their higher incomes may well be channeled into other assets and expenditures, as their development continues.

\footnotetext{
${ }^{9}$ See, for example, Jordan (1998), Aslam (1999), China Daily (2007), and Prakash (2007).
} 


\begin{tabular}{|c|c|c|c|c|}
\hline \multirow[b]{2}{*}{ Category } & \multirow[b]{2}{*}{ Definition } & \multicolumn{2}{|c|}{$\begin{array}{l}\text { Average gold demand, } \\
1997-2002 \text { (in tons) }\end{array}$} & \multirow{2}{*}{$\begin{array}{c}\% \\
\text { of } \\
\text { total }\end{array}$} \\
\hline & & $\begin{array}{l}\text { Developed } \\
\text { countries }\end{array}$ & $\begin{array}{l}\text { Developing } \\
\text { countries }\end{array}$ & \\
\hline Jewelry & $\begin{array}{l}\text { Includes all carat jewelry newly made from raw gold, } \\
\text { including gem-set jewelry. It excludes jewelry of other } \\
\text { metals clad or plated with gold as well as coins and bars } \\
\text { used as jewelry. Second- hand jewelry is also excluded } \\
\text { unless re-melted and sold for cash. Purchases funded by } \\
\text { trading in existing jewelry are not included. }\end{array}$ & 634.6 & $2,468.9$ & 81.2 \\
\hline $\begin{array}{l}\text { Retail } \\
\text { investment }\end{array}$ & $\begin{array}{l}\text { Includes coins minted after } 1800 \text { which are not less than } \\
900 \text { fineness, are or have been legal tender in the } \\
\text { country of origin, and are not sold for more than } 180 \\
\text { per cent of the value of their gold content; bars of one } \\
\text { kilogram or less that are purchased by investors; and } \\
\text { medallions of at least } 99 \% \text { purity. It excludes second- } \\
\text { hand coins which have not been re-melted and sold for } \\
\text { cash. }\end{array}$ & 133.0 & 189.5 & 8.4 \\
\hline $\begin{array}{l}\text { Total } \\
\text { consumer }\end{array}$ & Jewelry + retail investment & 767.7 & $2,658.3$ & 89.6 \\
\hline Industrial & $\begin{array}{l}\text { This category covers the first transformation of raw } \\
\text { gold (e.g. fine gold kilobars) into intermediate products } \\
\text { for industrial uses such as gold potassium cyanide, gold } \\
\text { bonding wire, and gold plating materials. }\end{array}$ & \multicolumn{2}{|c|}{329.6} & 8.6 \\
\hline Dental & $\begin{array}{l}\text { This category covers the first transformation of raw } \\
\text { gold into intermediate products for dental applications } \\
\text { such as dental alloys. }\end{array}$ & \multicolumn{2}{|c|}{67.8} & 1.8 \\
\hline $\begin{array}{l}\text { Overall } \\
\text { total }\end{array}$ & Jewelry + retail investment + industrial + dental & \multicolumn{2}{|c|}{$3,823.4$} & 100 \\
\hline
\end{tabular}




\begin{tabular}{|c|c|c|}
\hline Variable & Definition & Data source \\
\hline $\mathrm{G}_{\mathrm{it}}$ & $\begin{array}{l}\text { Log of gold imports per capita, in } \\
\text { grams. Includes jewelry, gold bars, } \\
\text { coins, medallions, and medals; } \\
\text { excludes gold intended for dental } \\
\text { and industrial uses. }\end{array}$ & World Gold Council \\
\hline GDP/capita & $\begin{array}{l}\text { Log of per capita GDP, in } 2000 \\
\text { constant US dollars adjusted for } \\
\text { purchasing power parity }\end{array}$ & Penn World Tables 6.2 \\
\hline $\begin{array}{l}\text { Growth in } \\
\text { GDP/capita }\end{array}$ & Growth in log of per capita GDP (\%) & Penn World Tables 6.2 \\
\hline $\begin{array}{l}\text { Volatility of } \\
\text { GDP/capita }\end{array}$ & $\begin{array}{l}\text { Standard deviation of growth rate } \\
\text { over the previous } 5 \text { years }\end{array}$ & $\begin{array}{l}\text { Computed from growth in } \\
\text { GDP/capita (see above). }\end{array}$ \\
\hline $\begin{array}{l}\text { Exchange-rate } \\
\text { volatility }\end{array}$ & $\begin{array}{l}\text { Standard deviation of appreciation } \\
\text { of the nominal exchange rate } \\
\text { against the U.S. dollar in the } \\
\text { previous } 5 \text { years }\end{array}$ & $\begin{array}{l}\text { Exchange rate data from Penn } \\
\text { World Tables } 6.2 \text {. The trade- } \\
\text { weighted exchange rate from the } \\
\text { St. Louis Fed's FRED data base is } \\
\text { used for the U.S. }\end{array}$ \\
\hline Inflation & Log of consumer price inflation & $\begin{array}{l}\text { World Bank, World Development } \\
\text { Indicators }\end{array}$ \\
\hline Inflation volatility & $\begin{array}{l}\text { Standard deviation of CPI inflation } \\
\text { over the previous } 5 \text { years }\end{array}$ & $\begin{array}{l}\text { Computed from inflation (see } \\
\text { above). }\end{array}$ \\
\hline $\begin{array}{l}\text { Change in gold } \\
\text { price }\end{array}$ & $\begin{array}{l}\text { Change in world price of gold in } \\
\text { constant domestic currency }\end{array}$ & $\begin{array}{l}\text { London PM fix quoted in US dollars, } \\
\text { as reported by the World Gold } \\
\text { Council; converted into domestic } \\
\text { currency using nominal exchange } \\
\text { rates from the Penn World Tables } \\
6.2 \text {, and inflation data from the } \\
\text { World Bank, World Development } \\
\text { indicators }\end{array}$ \\
\hline Credit market & Private credit as a share of GDP & $\begin{array}{l}\text { World Bank, World Development } \\
\text { Indicators }\end{array}$ \\
\hline Real interest rate & $\begin{array}{l}\text { Real deposit interest: Nominal rate } \\
\text { minus CPI inflation }\end{array}$ & $\begin{array}{l}\text { World Bank, World Development } \\
\text { Indicators, supplemented with data } \\
\text { from the International Monetary } \\
\text { Fund's International Financial } \\
\text { Statistics (for India), the St. Louis } \\
\text { Fed's FRED data base (for the US), } \\
\text { and the Bank of England (for the } \\
\text { UK) }\end{array}$ \\
\hline Stock market & $\begin{array}{l}\text { Stock market capitalization as a } \\
\text { share of GDP }\end{array}$ & $\begin{array}{l}\text { World Bank, World Development } \\
\text { Indicators }\end{array}$ \\
\hline
\end{tabular}


Table 3. Total consumer demand for gold (jewelry + retail-investment), full sample, 1992-2003 (n=230)

\begin{tabular}{|c|c|c|c|c|c|c|c|c|c|c|}
\hline & \multicolumn{2}{|c|}{ Pooled OLS } & \multicolumn{2}{|c|}{ Fixed-effects } & \multicolumn{2}{|c|}{ Bias-corrected LSDV } & \multicolumn{2}{|c|}{ GMM-difference } & \multicolumn{2}{|c|}{ GMM-system } \\
\hline & Coeff. & s.e. & Coeff. & s.e. & Coeff. & s.e. & Coeff. & s.e. & Coeff. & s.e. \\
\hline Git-1 & $.8757 *$ & .0333 & $.5817^{*}$ & .0846 & $.6752 *$ & .0518 & $.5184 *$ & .1347 & $.8484 *$ & .0571 \\
\hline GDP/capita & -.0068 & .0128 & $.2523+$ & .1418 & .2470 & .1757 & -.1599 & .2453 & -.0222 & .0339 \\
\hline $\begin{array}{l}\text { Growth in } \\
\text { GDP/capita }\end{array}$ & $-.0093 *$ & .0034 & -.0045 & .0038 & -.0060 & .0045 & $-.0060+$ & .0035 & $-.0098 *$ & .0052 \\
\hline $\begin{array}{l}\text { Volatility in } \\
\text { GDP/capita }\end{array}$ & $.0161 *$ & .0050 & $.0109 *$ & .0053 & .0078 & .0071 & $.0229+$ & .0120 & $.0209 *$ & .0067 \\
\hline $\begin{array}{l}\text { Exchange-rate } \\
\text { volatility }\end{array}$ & .0001 & .0001 & .0000 & .0001 & .0000 & .0001 & -.0001 & .0002 & .0005 & .0004 \\
\hline Inflation & -.0103 & .0105 & $.0242+$ & .0145 & .0209 & .0167 & .0129 & .0177 & -.0051 & .0183 \\
\hline Inflation volatility & -.0146 & .0114 & -.0128 & .0134 & -.0089 & .0297 & -.0267 & .0294 & -.0718 & .0584 \\
\hline Change in gold price & .0005 & .0008 & .0001 & .0008 & .0002 & .0016 & $.0015^{*}$ & .0007 & .0010 & .0009 \\
\hline Credit market & -.0004 & .0003 & $-.0019 *$ & .0009 & -.0017 & .0015 & $-.0046 *$ & .0020 & -.0006 & .0004 \\
\hline Real interest rate & .0000 & .0000 & -.0001 & .0000 & .0000 & .0000 & .0000 & .0001 & .0000 & .0000 \\
\hline Stock market & .0003 & .0003 & $.0013^{*}$ & .0005 & $.0012 *$ & .0006 & $.0014^{*}$ & .0008 & $.0005^{*}$ & .0003 \\
\hline Year dummies (p-val) & \multicolumn{2}{|c|}{$[.0000]$} & \multicolumn{2}{|c|}{$[.0000]$} & \multicolumn{2}{|c|}{$[.0000]$} & \multicolumn{2}{|c|}{$[.0002]$} & \multicolumn{2}{|c|}{$[.0000]$} \\
\hline Diagnostic tests & \multicolumn{2}{|c|}{$\begin{array}{c}\text { Rmse }=.1737 \\
\mathrm{R} 2=.9421\end{array}$} & \multicolumn{2}{|c|}{$\begin{array}{c}\text { Rmse }=.1630 \\
\mathrm{R} 2=.9539\end{array}$} & \multicolumn{2}{|c|}{ Rmse $=.1913$} & \multicolumn{2}{|c|}{$\begin{array}{l}\text { Sargan test }=1.000 \\
1^{\text {st }} \text { order AR: } 0.6499 \\
2^{\text {nd }} \text { order AR: } 0.6118\end{array}$} & \multicolumn{2}{|c|}{$\begin{array}{l}\text { Hansen test }=1.000 \\
1^{\text {st }} \text { order AR: } 0.084 \\
2^{\text {nd }} \text { order AR: } 0.331\end{array}$} \\
\hline
\end{tabular}

* = significant at $5 \%$ level. + = significant at $10 \%$ level.

Note: All regressions include year dummies. Details of regression specifications and standard errors are given in Appendix Table 2. 


\begin{tabular}{|l|c|c|}
\hline \multicolumn{3}{|l|}{ Table 4. Estimated country-specific fixed-effects } \\
\hline & Coeff. & s.e. \\
\hline Developing countries & & \\
\hline Brazil & .0109 & .0487 \\
\hline China & $.3665^{*}$ & .1656 \\
\hline Egypt & $.4524^{*}$ & .1202 \\
\hline Hong Kong & .0522 & .2351 \\
\hline India & $.3657^{*}$ & .1716 \\
\hline Indonesia & $.2051+$ & .1145 \\
\hline Korea & .1031 & .1197 \\
\hline Kuwait & $.6529 *$ & .2239 \\
\hline Malaysia & .0781 & .1210 \\
\hline Mexico (omitted) & -- & -- \\
\hline Pakistan & $.3050+$ & .1601 \\
\hline Saudi & $.6777 *$ & .1741 \\
\hline Singapore & .1597 & .1910 \\
\hline Thailand & $.2749+$ & .1440 \\
\hline Vietnam & $.5982^{*}$ & .2406 \\
\hline Developed countries & & \\
\hline France & -.1872 & .1646 \\
\hline Germany & -.0265 & .1655 \\
\hline Italy & .0879 & .1518 \\
\hline Japan & .1742 & .1900 \\
\hline UK & -.0480 & .1644 \\
\hline US & .0858 & .2208 \\
\hline
\end{tabular}

* = significant at $5 \%$ level. $+=$ significant at $10 \%$ level.

Note: Derived from the fixed-effects regression shown in Table 3. 
Table 5. Total consumer demand for gold, developing vs. developed countries, 1992-2003

\begin{tabular}{|c|c|c|c|c|c|c|c|c|c|c|}
\hline & \multicolumn{2}{|c|}{ Pooled OLS } & \multicolumn{2}{|c|}{ Fixed-effects } & \multicolumn{2}{|c|}{$\begin{array}{c}\text { Bias-corrected } \\
\text { LSDV }\end{array}$} & \multicolumn{2}{|c|}{ GMM-difference } & \multicolumn{2}{|c|}{ GMM-system } \\
\hline & Coeff. & s.e. & Coeff. & s.e. & Coeff. & s.e. & Coeff. & s.e. & Coeff. & s.e. \\
\hline \multicolumn{11}{|l|}{$\begin{array}{l}\text { DEVELOPING COUNTRIES } \\
(\mathrm{n}=164)\end{array}$} \\
\hline Git-1 & $.8839 *$ & .0365 & $.5837 *$ & .0978 & $.6783 *$ & .0440 & $.4936 *$ & .1402 & $.8767 *$ & .0588 \\
\hline GDP/capita & -.0318 & .0200 & .2466 & .1584 & .2249 & .1751 & -.0190 & .2462 & -.0586 & .0542 \\
\hline Growth in GDP/capita & $-.0101 *$ & .0039 & -.0046 & .0043 & -.0057 & .0065 & $-.0052+$ & .0031 & $-.0082+$ & .0045 \\
\hline Volatility in GDP/capita & $.0172 *$ & .0066 & .0091 & .0056 & .0060 & .0063 & $.0207+$ & .0108 & $.0233 *$ & .0080 \\
\hline Exchange-rate volatility & .0001 & .0001 & .0000 & .0001 & .0000 & .0001 & .0001 & .0003 & $.0009 *$ & .0004 \\
\hline Inflation & $-.0269 *$ & .0127 & .0108 & .0167 & .0095 & .0188 & -.0007 & .0204 & -.0024 & .0240 \\
\hline Inflation volatility & -.0085 & .0112 & -.0091 & .0160 & -.0029 & .0220 & -.0556 & .0370 & $-.1346 *$ & .0504 \\
\hline Change in gold price & .0007 & .0010 & .0001 & .0009 & .0002 & .0022 & .0004 & .0011 & .0005 & .0014 \\
\hline Credit market & -.0007 & .0004 & $-.0024 *$ & .0012 & $-.0021+$ & .0011 & $-.0047 *$ & .0019 & -.0010 & .0008 \\
\hline Real interest rate & .0000 & .0000 & .0000 & .0000 & .0000 & .0000 & .0000 & .0001 & .0000 & .0000 \\
\hline Stock market & .0005 & .0003 & $.0010+$ & .0006 & .0010 & .0007 & .0012 & .0009 & .0006 & .0004 \\
\hline \multicolumn{11}{|l|}{$\begin{array}{l}\text { DEVELOPED COUNTRIES } \\
(\mathrm{n}=66)\end{array}$} \\
\hline Git-1 & $.8668^{*}$ & .0536 & $.2646 *$ & .1082 & $.4085 *$ & .2126 & $.2646 *$ & .0674 & $.6911^{*}$ & .1262 \\
\hline GDP/capita & .0086 & .2258 & $2.3245^{*}$ & .5505 & $1.8247^{*}$ & .8191 & $2.3245^{*}$ & .4189 & -.0978 & .2083 \\
\hline Growth in GDP/capita & -.0083 & .0258 & $-.0211+$ & .0120 & -.0188 & .0146 & $-.0211+$ & .0127 & -.0004 & .0168 \\
\hline Volatility in GDP/capita & .0291 & .0384 & $.0820 *$ & .0297 & $.0855 *$ & .0192 & $.0820 *$ & .0231 & .0392 & .0321 \\
\hline Exchange-rate volatility & -.0036 & .0054 & -.0053 & .0048 & -.0071 & .0135 & -.0053 & .0041 & -.0035 & .0036 \\
\hline Inflation & .0415 & .0446 & -.0044 & .0327 & -.0037 & .0571 & -.0044 & .0302 & $.0783+$ & .0375 \\
\hline Inflation volatility & -.0194 & .0152 & $-.0995 *$ & .0270 & $-.0952 *$ & .0133 & $-.0995 *$ & .0174 & -.0605 & .0340 \\
\hline Change in gold price & .0018 & .0010 & .0024 & .0017 & $.0021 *$ & .0006 & $.0024 *$ & .0010 & $.0040 *$ & .0015 \\
\hline Credit market & .0000 & .0007 & $-.0020 *$ & .0009 & -.0019 & .0018 & $-.0020 *$ & .0006 & .0006 & .0007 \\
\hline Real interest rate & -.0020 & .0044 & $.0206 *$ & .0095 & .0209 & .0209 & $.0206+$ & .0111 & -.0012 & .0066 \\
\hline Stock market & .0004 & .0008 & $.0014+$ & .0008 & .0016 & .0016 & $.0014 *$ & .0007 & .0000 & .0007 \\
\hline
\end{tabular}

* = significant at $5 \%$ level. $+=$ significant at $10 \%$ level.

Note: All regressions include year dummies. Details of regression specifications and diagnostic tests are given in Appendix Tables 2 and 3 respectively. 


\begin{tabular}{|c|c|c|c|c|c|c|c|c|c|c|}
\hline & \multicolumn{2}{|c|}{ Pooled OLS } & \multicolumn{2}{|c|}{ Fixed-effects } & \multicolumn{2}{|c|}{$\begin{array}{c}\text { Bias-corrected } \\
\text { LSDV }\end{array}$} & \multicolumn{2}{|c|}{ GMM-difference } & \multicolumn{2}{|c|}{ GMM-system } \\
\hline & Coeff. & s.e. & Coeff. & s.e. & Coeff. & s.e. & Coeff. & s.e. & Coeff. & s.e. \\
\hline \multicolumn{11}{|l|}{ JEWELRY DEMAND } \\
\hline Git-1 & $.9377 *$ & .0136 & $.8601 *$ & .0625 & $.9587 *$ & .0470 & $.9845^{*}$ & .0919 & $.9106 *$ & .0174 \\
\hline GDP/capita & -.0062 & .0067 & .0295 & .0749 & -.0146 & .1020 & $-.3374 *$ & .1524 & -.0051 & .0145 \\
\hline Growth in GDP/capita & $-.0039+$ & .0019 & $-.0043 *$ & .0021 & $-.0054 *$ & .0021 & -.0033 & .0030 & $-.0053 *$ & .0022 \\
\hline Volatility in GDP/capita & $.0056 *$ & .0019 & $.0062 *$ & .0026 & .0048 & .0038 & $.0126 *$ & .0058 & $.0088^{*}$ & .0027 \\
\hline Exchange-rate volatility & .0000 & .0000 & .0000 & .0001 & .0000 & .0001 & .0001 & .0001 & .0001 & .0002 \\
\hline Inflation & -.0019 & .0061 & $.0130+$ & .0076 & .0103 & .0085 & $.0204 *$ & .0109 & -.0022 & .0075 \\
\hline Inflation volatility & -.0103 & .0067 & -.0033 & .0073 & -.0015 & .0134 & -.0113 & .0155 & -.0243 & .0230 \\
\hline Change in gold price & .0001 & .0008 & .0001 & .0005 & .0002 & .0008 & .0009 & .0007 & -.0003 & .0009 \\
\hline Credit market & -.0002 & .0002 & $-.0008 *$ & .0004 & -.0006 & .0007 & -.0007 & .0006 & $-.0004+$ & .0002 \\
\hline Real interest rate & .0000 & .0000 & .0000 & .0000 & .0000 & .0000 & .0000 & .0000 & .0000 & .0000 \\
\hline Stock market & .0001 & .0001 & $.0007 *$ & .0003 & $.0007 *$ & .0003 & $.0011 *$ & .0006 & $.0003 *$ & .0001 \\
\hline \multicolumn{11}{|l|}{ RETAIL INVESTMENT } \\
\hline Git-1 & .3171 & .1884 & .1693 & .1324 & $.2431^{*}$ & .0707 & $2028+$ & .1218 & $.3500 *$ & .0904 \\
\hline GDP/capita & $-.0759+$ & .0440 & .7974 & .5175 & .6615 & .8743 & .6472 & .5057 & -.0663 & .0448 \\
\hline Growth in GDP/capita & -.0194 & .0143 & -.0182 & .0212 & -.0182 & .0157 & $-.0336 *$ & .0128 & -.0276 & .0175 \\
\hline Volatility in GDP/capita & $.0475 *$ & .0114 & .0115 & .0360 & .0067 & .0191 & $.0275 *$ & .0109 & $.0366 *$ & .0076 \\
\hline Exchange-rate volatility & -.0001 & .0002 & -.0002 & .0003 & -.0002 & .0006 & -.0005 & .0004 & -.0007 & .0011 \\
\hline Inflation & $-.0696 *$ & .0306 & -.0193 & .0492 & -.0183 & .0324 & -.0559 & .0459 & $-.0826 *$ & .0379 \\
\hline Inflation volatility & .0219 & .0298 & .0054 & .0270 & .0107 & .0797 & .0207 & .0359 & .1172 & .1479 \\
\hline Change in gold price & -.0021 & .0026 & -.0021 & .0025 & -.0019 & .0072 & -.0025 & .0020 & -.0022 & .0027 \\
\hline Credit market & .0008 & .0011 & -.0038 & .0023 & -.0036 & .0031 & -.0045 & 0030 & .0007 & .0009 \\
\hline Real interest rate & .0000 & .0001 & .0000 & .0001 & .0000 & .0001 & .0000 & .0001 & .0000 & .0001 \\
\hline Stock market & .0000 & .0008 & $.0035 *$ & .0014 & $.0035^{*}$ & .0009 & $.0055+$ & .0029 & .0006 & .0010 \\
\hline
\end{tabular}

Note: All regressions include year dummies. Details of regression specifications and diagnostic tests are given in Appendix Tables 2 and 3 respectively. 
Figure 1. Consumer demand for gold, 1997-2002 (in tonnes)

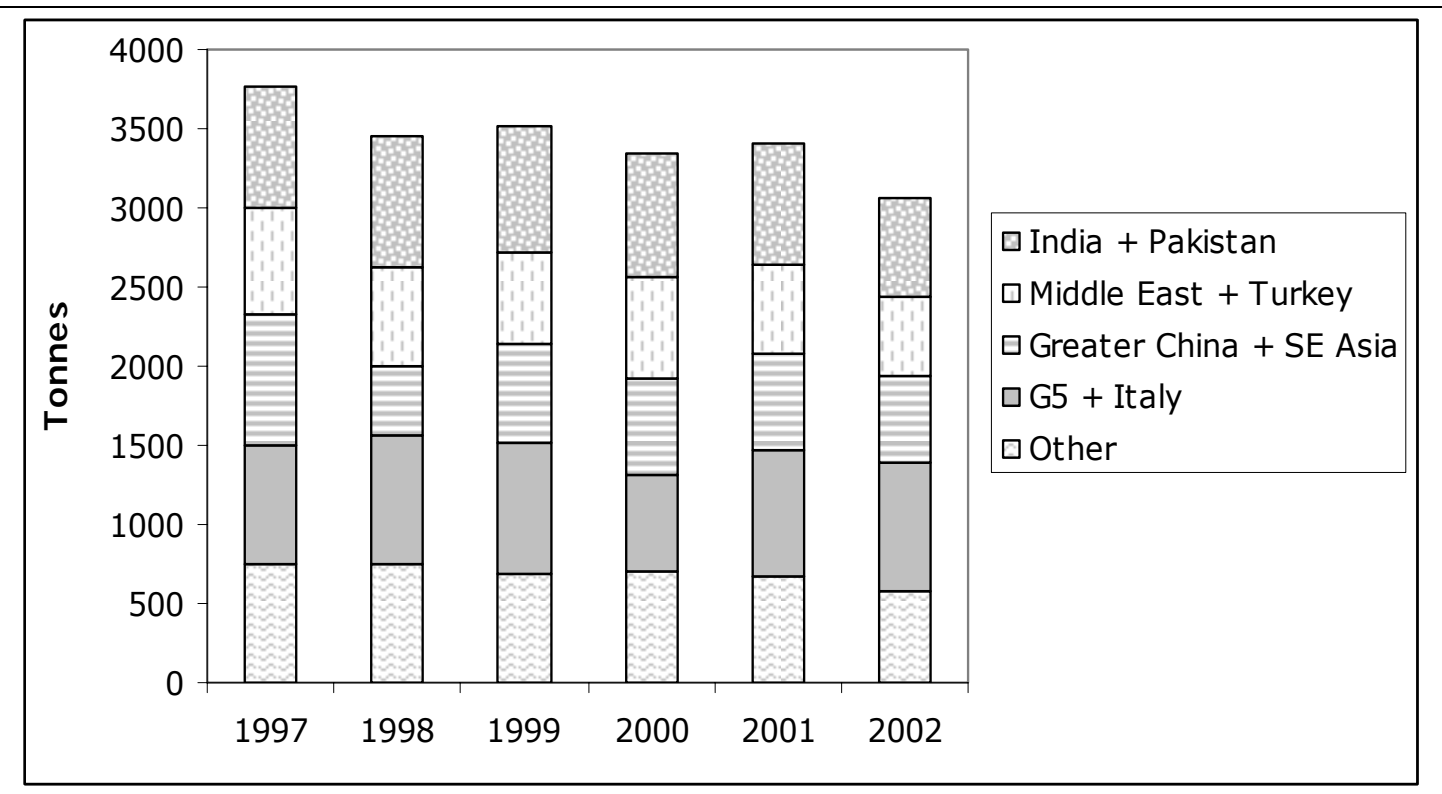

Source: World Gold Council (2006). 
Figure 2. Consumer demand for gold versus real GDP per capita (2002)

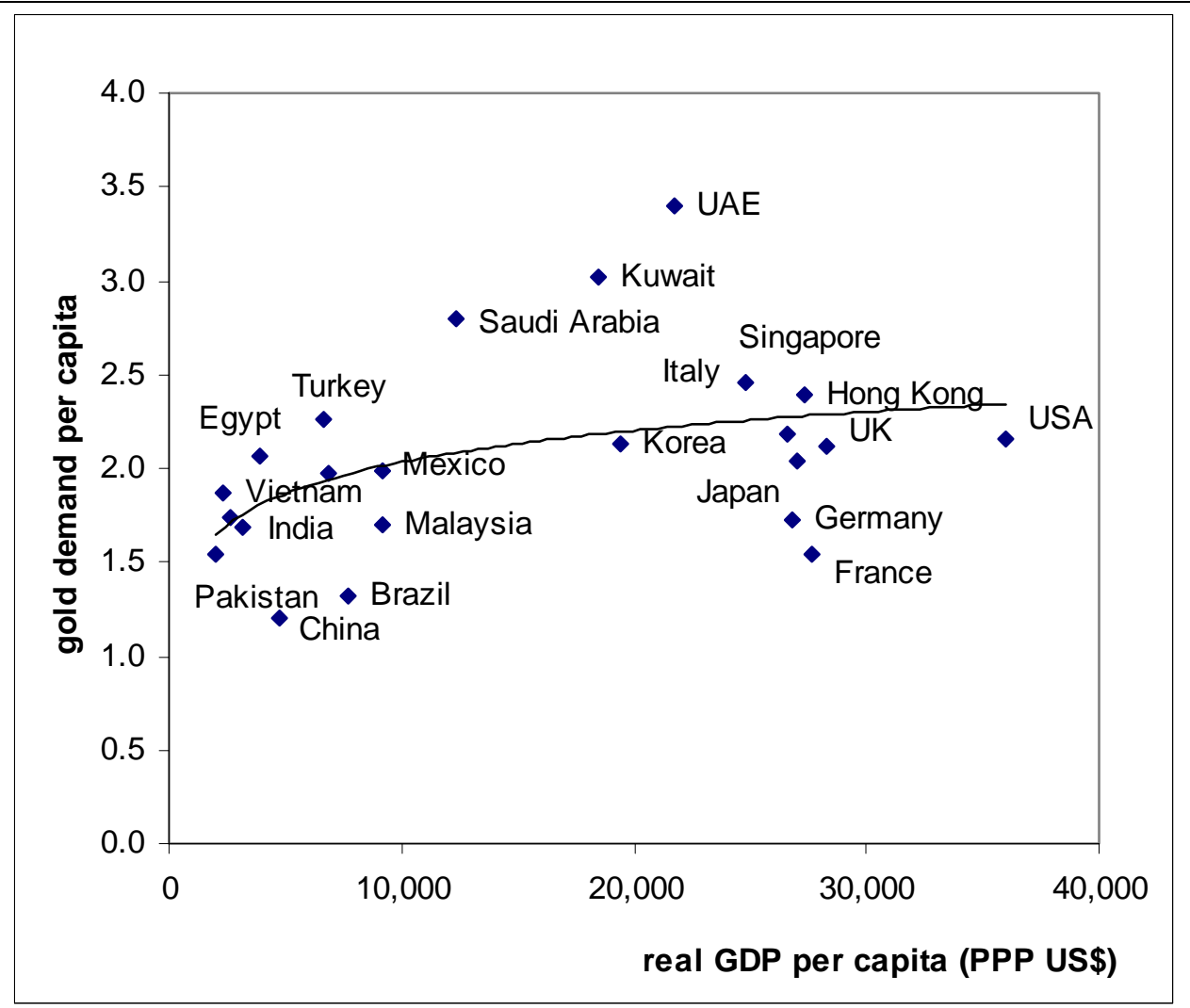

Source: World Gold Council. Scale of vertical axis is log of $\{1 / 1000$ troy oz. per capita $\}$ 


\section{$\underline{\text { References }}$}

Algahtani, Ibrahim M. (1992). "Currency Substitution, Gold Price and the Demand for Money in a Developing Economy: The Case of Kuwait," Middle East Business and Economic Review, vol. 4, no. 2 (July), pp. 1-5

Arellano, Manuel, and Stephen Bond (1992). "Some Tests of Specification for Panel Data: Monte Carlo Evidence and an Application to Employment Equations," Review of Economic Studies, Vol. 58, pp. 277-297.

and Olympia Bover (1995). "Another Look at the Instrumental-Variable Estimation of Error-Component Models,” J ournal of Econometrics, Vol. 68, pp, 29-52.

Syed M. Aslam (1999). “Pakistan's Gold Trade,” Pakistan Economist (Feb. 22-28). Accessed electronically at http://www.pakistaneconomist.com/database1/cover/c99-8.asp, on July 18, 2007.

Bailey, Warren (1987). "An Empirical Investigation of the Market for Comex Gold Futures Options," J ournal of Finance, vol. 42, no. 5 (Dec.), pp. 1187-94

Balassa, Bela (1990). "The Effects of Interest Rates on Savings in Developing Countries," Banca Nazionale del Lavoro Quarterly Review, no. 172 (March), pp. 101-18.

Beckers, Stan (1984). “On the Efficiency of the Gold Options Market," J ournal of Banking and Finance, Vol. 8, pp. 459-70.

Bhattacharya, Himadri (2002). "The deregulation of gold in India." World Gold Council Report No. 27 (March).

Blundell, R. and S. Bond. (1998). "Initial conditions and moment restrictions in dynamic panel data models." J ournal of Econometrics, Vol. 87, No. 1, pp. 115-143.

Bruno, G.S.F. (2005). "Approximating the bias of the LSDV estimator for dynamic unbalanced panel data models,” Economics Letters, 87, pp. 361-366.

Cai, Jun, Yan-Leung Cheung, Michael Wong (2001). "What Moves the Gold Market?” J ournal of Futures Markets, vol. 21, no. 3 (March), pp. 257-78

Capie, Forrest, Terence C. Mills, and Geoffrey Wood (2005). “Gold as a Hedge against the Dollar," J ournal of International Financial Markets, Institutions and Money, vol. 15, no. 4, October 2005, pp. 343-52

Chandavarkar, A. G. (1961). "The Nature and Effects of Gold Hoarding in Under-Developed Economies," Oxford Economic Papers, New Series, Vol. 13, No. 2. (Jun., 1961), pp. 137-148.

China Daily (2007). “Big spenders go for gold in New Year's rush” (Feb. 24). Posted on China Economic Net and accessed electronically at http://en.ce.cn/stock/marketnews/200702/24/t20070224_10490210.shtml, on July 18, 2007.

Haugom, Howard N (1991). "The Supply and Demand for Gold”. Ph.D. dissertation, Simon Fraser University.

Jordan, Miriam (1998). “Demand is Constant/An 'Excessive Fondness': For Indians, Ignoring World, All that Glitters is Gold," International Herald Tribune (Feb. 26). 
Keynes, John Maynard (1913). Indian Currency and Finance. London: Macmillan.

London: Macmillan.

(1936). The General Theory of Employment, Interest and Money.

Kutan, Ali and Tansu Aksoy (2004). "Public Information Arrival and Gold Market Returns in Emerging Markets: Evidence from the Istanbul Gold Exchange," Scientific J ournal of Administrative Development, vol. 2, pp. 13-26

Prakash, Atul (2007). "India's appetite for gold insatiable as ever." Reuters News Service (Apr. 22).

Rao, B. S. and K. Nagabhushanam (1960), "India's Demand for Import of Non-Monetary Gold, Non-Monetary Silver and Merchandise, 1901-1913," Indian Economics J ournal, Vol. 48, No. 3, pp. 34-38.

Sjaastad, Larry A; Scacciavillani, Fabio (1996). "The Price of Gold and the Exchange Rate," J ournal of International Money and Finance, vol. 15, no. 6 (Dec.), pp. 879-97

Smith, Graham (2002). "Tests of the Random Walk Hypothesis for London Gold Prices," Applied Economics Letters, vol. 9, no. 10 (Aug.), pp. 671-74

Tran, Ky and Martha Starr (2007). "Monetary policy in Vietnam: An SVAR analysis of the role of gold." American University, Working Paper.

World Gold Council (2006). "Official gold reserve statistics” (Sept.). Accessed electronically on Nov. 10, 2006, at http://www.gold.org/value/stats/statistics/archive/index.php?issue=statorderid20-09-2006.html.

(2007). "Gold knowledge homepage: FAQs." Accessed electronically on June 29, 2007, at http://www.gold.org/discover/knowledge/faqs/index.html. 


\begin{tabular}{|c|c|c|c|}
\hline \multicolumn{4}{|c|}{ Appendix Table 1. List of sample countries } \\
\hline & \multicolumn{3}{|c|}{$\begin{array}{c}\text { Average per-capita gold imports, } \\
1992-2003 \text { (in grams) }\end{array}$} \\
\hline & $\begin{array}{c}\text { Total } \\
\text { consumer }\end{array}$ & Jewelry & Investment \\
\hline \multicolumn{4}{|l|}{ Developing } \\
\hline Brazil & .2167 & .2376 & -.0208 \\
\hline China & .2320 & .2167 & .0153 \\
\hline Egypt & 1.5400 & 1.5123 & .0277 \\
\hline Hong Kong & 5.5241 & 5.3960 & .1268 \\
\hline India & .5653 & .4771 & .0883 \\
\hline Indonesia & .4774 & .4579 & .0195 \\
\hline Korea & 1.3293 & 1.2335 & .0958 \\
\hline Kuwait & 17.7698 & 15.5668 & 2.2065 \\
\hline Malaysia & .9968 & .8486 & .1482 \\
\hline Mexico & .4794 & .4641 & .0153 \\
\hline Pakistan & .3925 & .3727 & .0198 \\
\hline Saudi Arabia & 9.1705 & 8.7000 & .4705 \\
\hline Singapore & 4.7317 & 4.3287 & .4009 \\
\hline Thailand & 1.0031 & .8028 & .2003 \\
\hline Vietnam & .6050 & .2122 & .3928 \\
\hline \multicolumn{4}{|l|}{ Developed } \\
\hline France & .3655 & .8492 & -.4836 \\
\hline Germany & .8500 & .6315 & .2185 \\
\hline Italy & 1.9359 & 1.9359 & n.a. \\
\hline Japan & 1.1456 & .6019 & .5437 \\
\hline U.K. & .9976 & .9976 & n.a. \\
\hline U.S. & 1.3164 & 1.2011 & .1153 \\
\hline
\end{tabular}




\begin{tabular}{|l|l|}
\hline \multicolumn{2}{|l|}{ Appendix Table 2. Details of regression specifications } \\
\hline Method & Estimation details \\
\hline Pooled OLS & $\begin{array}{l}\text { Huber-White standard errors robust to correlation of errors within } \\
\text { but not across clusters (in this case, countries) }\end{array}$ \\
\hline Fixed-effects & Prais-Winsten models with panel-corrected standard errors \\
\hline Bias-corrected LSDV & $\begin{array}{l}\text { Estimated using Giovanni Bruno's (2005) .ado Stata routine. } \\
\text { Bootstrap standard errors. }\end{array}$ \\
\hline GMM-difference & $\begin{array}{l}\text { Robust standard errors. The Sargan test indicates whether the over- } \\
\text { identifying restrictions can be rejected by the data. Tests for } 1^{\text {st }} \text { and } \\
2^{\text {nd }} \text { order autocorrelation are taken from two-step estimates; if it is } \\
\text { possible to reject the null of no } 2^{\text {nd }} \text { order autocorrelation, the results } \\
\text { would be inconsistent. }\end{array}$ \\
\hline GMM-system & $\begin{array}{l}\text { Estimated using David Malin Roodman's XTABOND2 .ado Stata } \\
\text { routine. Standard errors are estimated robustly. The Hansen test } \\
\text { indicates whether the over-identifying restrictions can be rejected } \\
\text { by the data. If the null of no } 2^{\text {nd }} \text { order autocorrelation can be } \\
\text { rejected, the results are inconsistent. }\end{array}$ \\
\hline
\end{tabular}




\begin{tabular}{|c|c|c|c|c|c|}
\hline & Pooled OLS & Fixed-effects & $\begin{array}{l}\text { Bias- } \\
\text { corrected } \\
\text { LSDV }\end{array}$ & GMM-difference & GMM-system \\
\hline \multicolumn{6}{|l|}{$\begin{array}{l}\text { Table 5: Consumer } \\
\text { demand }\end{array}$} \\
\hline $\begin{array}{l}\text { Developing } \\
\text { countries }(n=164)\end{array}$ & $\begin{array}{c}\text { Rmse }=.1873 \\
\mathrm{R} 2=.9511\end{array}$ & $\begin{aligned} \mathrm{Rmse} & =.1797 \\
\mathrm{R} 2 & =.9514\end{aligned}$ & Rmse $=.2125$ & $\begin{array}{c}\text { Sargan test }= \\
1.000 \\
1^{\text {st }} \text { order AR } .821 \\
2^{\text {nd }} \text { order AR: } .536\end{array}$ & $\begin{array}{c}\text { Hansen test }= \\
1.000 \\
1^{\text {st }} \text { order AR: } .017 \\
2^{\text {nd }} \text { order AR: } .202\end{array}$ \\
\hline $\begin{array}{l}\text { Developed } \\
\text { countries }(n=66)\end{array}$ & $\begin{array}{c}\text { Rmse }=.1053 \\
\mathrm{R} 2=.8917\end{array}$ & $\begin{aligned} \mathrm{Rmse} & =.0836 \\
\mathrm{R} 2 & =.9395\end{aligned}$ & Rmse $=.3284$ & $\begin{array}{c}\text { Sargan test }= \\
1.000 \\
1^{\text {st }} \text { order AR: } .387 \\
2^{\text {nd }} \text { order AR: } .379\end{array}$ & $\begin{array}{c}\text { Hansen test }= \\
1.000 \\
1^{\text {st }} \text { order AR: } .146 \\
2^{\text {nd }} \text { order AR: } .216 \\
\end{array}$ \\
\hline \multicolumn{6}{|l|}{$\begin{array}{l}\text { Table } 6 \text { : Demand } \\
\text { by type }\end{array}$} \\
\hline Jewelry & $\begin{array}{c}\text { Rmse }=.0872 \\
\mathrm{R} 2=.9850\end{array}$ & $\begin{aligned} \mathrm{Rmse} & =.0842 \\
\mathrm{R} 2 & =.9873\end{aligned}$ & Rmse $=.318$ & $\begin{array}{c}\text { Sargan test }= \\
1.000 \\
1^{\text {st }} \text { order AR: } .147 \\
2^{\text {nd }} \text { order AR: } .901\end{array}$ & $\begin{array}{c}\text { Hansen test }= \\
1.000 \\
1^{\text {st }} \text { order AR: } .006 \\
2^{\text {nd }} \text { order AR: } .574\end{array}$ \\
\hline Retail investment & $\begin{array}{c}\mathrm{Rmse}=.4982 \\
\mathrm{R} 2=.2868\end{array}$ & $\begin{array}{c}\mathrm{Rmse}=.0842 \\
\mathrm{R} 2=.4586\end{array}$ & Rmse $=.3284$ & $\begin{array}{c}\text { Sargan test }= \\
1.000 \\
1^{\text {st }} \text { order AR: } .343 \\
2^{\text {nd }} \text { order AR: } .432\end{array}$ & $\begin{array}{c}\text { Hansen test }= \\
1.000 \\
1^{\text {st }} \text { order AR: } .361 \\
2^{\text {nd }} \text { order AR: } .401\end{array}$ \\
\hline
\end{tabular}

